\title{
ISI PESAN DAN KREATIVITAS IKLAN SHOPEE VERSI "PAK JOKOWI BAGI-BAGI SEPEDA"
}

\author{
Masrurul Laily \\ Jurusan Komunikasi dan Penyiaran Islam, FUAD IAIN Tulungagung \\ (email : masrurul.laily@ gmail.com)
}

\begin{abstract}
ABSTRAK
Penilitian ini bertujuan untuk menemukan kreatifitas pengiklan dan mengetahui tentang isi pesan yang terkandung dalam iklan shopee versi "pak Jokowi bagi-bagi sepeda". Pada Jurnal kali ini kami akan membuat pengamatan melalui metode kualitatif dengan cara mengamati melalui ilmu semiotika menurut Roland Barthes yang terkandung dalam iklan tersebut dan beberapa pengamatan tentanga alur cerita, suasana dan body language. Sehingga pembaca akan mengetahui apakah cerita yang kreator iklan Shopee dibuat berlebihan dan malah tidak sesuai atau sebaliknya. Hasil dari penelitian ini menunjukkan bahwa iklan shopee sangat menghibur dan isi pesannya pun sampai kepada para pemirsa. Iklan ini sangat-sangat menarik dan mudah di ingat oleh pemirsa.
\end{abstract}

\section{Kata kunci : Iklan, Kreatifitas, Isi Pesan, Shopee.}

ABSTRAC

This research aims to find advertisers' creativity and find out about the content of messages contained in shopee advertisements, "Pak Jokowi's share of bicycles". In this journal we will make observations through qualitative methods by observing through semiotics according to Roland Barthes contained in the ad and some observations about the storyline, atmosphere and body language. So that the reader will find out whether the stories that Shopee's ad creators are made are excessive and even inappropriate or vice versa. The results of this study indicate that shopee ads are very entertaining and the content of the message reaches the viewers. According to Barthes' semiotics method, the markers used also understand the viewers who are watching, as well as interesting or not, this ad is very, very interesting and easily remembered by viewers.

Keyword : Advertising, Creativity, Message Content, Shopee.

\section{PENDAHULUAN}

Menurut Nastiti dan Utomo (2015) minat beli adalah puncak efek sebelum tindakan pembelian dari komunikasi pemasaran. Helmi dkk., (2016) menyatakan minat seseorang untuk membeli merupakan suatu keinginan untuk membeli produk atau jasa karena dipengaruh oleh pengaruh eksternal ataaupun internal 
yang dimana sebelumnya telah dilakukan sebuah evaluasi terhadap suatu produk tertentu yang nantinya akan dibeli oleh orang tersebut. Strategi yang tempat harus dipaling efektif adalah perusahaan harus mengetahui segmentasi yang akan dituju (Huda, 2009).

Seiring dengan berjalannya kemajuan media online, beberapa perusahaanperusahaan besar mulai membuat sebuah formula mobile marketplace yang mempermudah masyarakat dengan memanfaatkan kecanggihan teknologi smartphone untuk melakukan proses jual beli. Sudah banyak sekali aplikasiaplikasi seperti ini yang menjamur di negara Indonesia. Semakin majunya peradaban modern ini membuat perkembangan teknologi menjadi lebih pesat. Iklan menjadi sebuah hal yang berperan sangat penting untuk memperkenalkan untuk memperkuat citra sebuah merek produk ataupun perusahaan tertentu. Selain televisi, saat ini praktisi-praktisi marketing juga tengah membidik beberapa media sosial yang kini tengah aktif digunakan oleh masyarakat seperti Instagram, Youtube dan lain-lain. Salah satu dari banyaknya perusahaan e-commerce atau market mobile place baru di negara Indonesia yang berkembang hingga sekarang ini yaitu Shopee. Untuk bersaing dengan perusahaan aplikasi e-commerce yang lain, Shopee melakukan berbagai strategi beriklan diberbagai mediasalah satu diantaranya adalah di media televisi. Shopee merupakan perusahaan e-commerce yang lebih aktif beriklan di televisi dari pada perusahaan lain (Huda \& Martanti, 2018).

Data hasil sebuah riset yang dikeluarkan oleh Nielsen Advertising Information Service menyatakan pada periode Januari - Juli 2017, produk-produk yang menjadi faktor terbesar untuk mendorong perkembangan iklan di Indonesia diantaranya yaitu pertumbuhan telekomunikasi dan juga layanan online yang masing-masing bertambah 32\% dan 31\% hingga mencapai $\mathrm{Rp} 3,7$ triliun dan $\mathrm{Rp}$ 3,2 triliun. Sedangkan untuk kategori layanan online, ada tiga buah pengiklan yang terbesar dan tentunya menjadi pendorong perkembangan pada periode ini adalah Agoda, Shopee, dan Traveloka. Selain itu, data dari Nielsen ini terdapat juga data dari Adensity.com yang juga menunjukan bahwasannya aplikasi Shopee sangatlah aktif dalam beriklan di media televisi. 
Dapat dilihat pada data di atas menunjukan bahwasannya jumlah iklan Aplikasi Shopee dalam periode seminggu terhitung pada tanggal 25 November 1 Desember 2017, iklan Shopee ditayangkan di televisi sebanyak 420 kali sehingga jumlah total keseluruhan belanja iklan tersebut sebanyak Rp. 12.310.700.000 di sepuluh televisi nasional yang ada di Indonesia. Bisa diambil kesimpulan bahwa ternyata hanya dengan menggunakan sebuah kepopularitasan seseorang dalam memasarkan sebuah produk menjadi jalan yang sangat baik untuk lebih meluaskan pemasaran produk itu sendiri.

Pendapat yang dikemukakan oleh Jefkins (1997) sangatlah sesuai yaitu iklan adalah sebuah media informasi yang dibuat dengan sekreatif mungkin serta sedemikian adanya agar mampu menarik minat publik, keaslian atau perdana dibuat dan juga memiliki karakteristik tertentu, menarik dan bersifat membujuk sehingga para pemirsa yang telah menjadi konsumen atau calon konsumen secara sukarela tertarik untuk melakukan transaksi atau menikmati produk yang telah dibuat dan juga sesuai dengan yang di harapkan oleh pengiklan atau perusahaan itu sendiri. Maka hanya dengan memasang iklan di televisi ataupun youtube dengan durasi satu menit lebih saja akan bisa di tonton oleh jutaan pasang mata yang tentu akan menarik minat mereka untuk menggunakan aplikasi tersebut dan dengan segala kreatifitas pembuat iklan tentunya. Karena tujuan iklan sebenarnya adalah memperkenalkan sebuah produk atau apapun untuk memperoleh penghasilan dalam jangka panjang di sebuah perusahaan pemasang iklan.

Kualitas pesan iklan juga perlu diperhatikan oleh kreator periklanan. Seharusnya sebuah iklan tidak hanya mengandung hal yang informatif saja, melainkan juga suatu hal yang dapat menarik perhatian masyarakat salah satunya dengan tayangan iklan yang menghibur. Karena ketika perhatian pemirsa sudah tertuju pada suatu iklan tersebut maka pesan yang terdapat pada iklan tersebut akan lebih mudah diserap oleh pemirsa. Maka dari itu, bisa dibilang bahwa kualitas iklan akan berpengaruh posistif pada suatu keefektivitasan sebuah iklan itu sendiri.

Suatu iklan jika ditayankan tepat pada jam-jam sasarannya dan di ulangulang akan memberikan hasil yang lebih efektif. Dalam penelitian yang dilakukan 
oleh Ray et al (dalam indiarto, 2006) menyatakan bahwasannya pengulangan suatu iklan sangat meningkatkan niat beli seseorang dan meningkatkan keinginan untuk berbelanja seseorang dalam iklan low-price convenience goods akan tetapi tidak untuk high-price shopping goods. Namun studi menyatakan menggunakan iklan di media televisi memiliki sebuah efek positif dalam pengulangan dan tidak untuk beberapa media sosial. Karena iklan yang banyak diulang-ulang akan lebih mudah untuk di ingat oleh pemirsa dengan tanpa sadar dan paksaan secara spontanitas.

\section{METODE PENELITIAN}

Metode yang digunakan dalam penelitian ini adalah dengan cara mengamati percakapan, bahasa tubuh (body language), suasana yang diciptakan dalam iklan, dan semiotika mengenai warna-warna atau barang-barang dan seluruh tanda penanda yang dipakai dalam iklan tersebut. Dan tentunya kami akan mengkaji warna orange sebagai cirikhas aplikasi shopee itu sendiri. Pada penelitian ini kami menggunakan semiotika versi Roland Barthes. Menurut Alex Sobut dalam bukunya yang berjudul Semiotika Komunikasi (2009) barthes sangat dikenal sebagai seorang ilmuan atau pemikir strukturalis yang sangat mahir dalam mempraktikkan ilmu mengenai linguistik dan semiology yang di ajarkan oleh Saussurean. Selain itu, belau juga begitu intelektual serta kritis sebagai seorang ilmuan ternama sastra dari Prancis, eksponen penerapan yang strukturalisme dan semiotika pada bidang studi sastra. Pada teori Roland Barthes (1915-1980), beliau mengembangkan ilmu semiotika terbagi menjadi 2 tingkatan pertanda, yakni konotasi dan denotasi. Kata konotasi sendiri yakni berasal dari bahasa Latin connotare, yaitu "menjadi makna" dan mengarah kepada tanda-tanda kultural yang terpisah atau bebeda dengan kata (serta banyak bentuk lain dari sebuah sistem komunikasi). Ternyata sebuah kata mutlak melibatkan simbol-simbol, historis serta yang ada hubungannya dengan emosional.

Roland Barthes,seseorang yang sudah biasanya disebut sebagai semiotikus terkenal dari Perancis dalam bukunya Mythologies (1972) menjelaskan tentang konotasi kultural dari berbagai aspek keseharian dalam kehidupan yang dilakukan oleh orang Perancis, misalnya steak dan frites, deterjen, mobil ciotron dan gulat. 
Menurut Barthes, tujuannya merupakan untuk membawa dunia tentang "apa-yang terjadi tanpa mengatakan" dan menunjukan konotasi pada kata "dunia" tersebut secara lebih luas lagi dasar idiologinya. Tidak hanya itu, Barthes juga telah melihat beberapa aspek lain pada pembahasan ini dari penandaan yakni "mitos" yang menandai kepada suatu masyarakat tertentu. Menurut Barthes "Mitos" terdapat pada tingkat kedua penandaan, maka setelah terbentuknya sebuah sistem sign-signifier-signified, tanda sebelumnya akan menjadi sebuah penanda yang baru dan kemudian mempunyai petanda yang kedua serta akan menjadi sebuah tanda yang baru. Maka dari itu, ketika sebuah tanda memiliki arti konotasi setelah itu berkembang menjadi arti denotasi, maka arti denotasi tersebut akan berubah menjadi sebuah "mitos".

Format pengamatan yang akan dilakukan dengan cara memetakan bagianbagian yang dirasa penting untuk dibahas seperti dialog, situasi maupun suasana yang terbangun, begitu juga dengan beberapa komponen figur-figur yang terdapat pada iklan shopee tersebut. Kami akan menjabarkan tentang apa saja makna yang tersirat pada setiap scene iklan shopee tersebut dan tentunya kami akan menyimpulkan apakah isi pesan yang terkandung pada iklan shopee itu sendiri.

\section{PEMBAHASAN}

\section{a. Kreatifitas Dan Isi Pesan Iklan}

Iklan yang kreatif akan efektif dikemukakan oleh Kover,Goldberg \& James (1995), Shapiro \& Krishnan (2001) dan Till \& Baack (2005). Iklan kreatif merupakan iklan yang dianggap original yaitu tidak meniru iklan lain yang pernah ada, iklan yang mencengangkan, tidak terduga, tidak disangka sangka, penuh arti dan bisa mempengaruhi emosi pemirsa. Iklan kreatif membuat audience memperhatikan iklan tersebut secara detail dan rinci. Sedangkan menurut pandangan yang dikemukakan oleh Shimp (2000) iklan yang kreatif merupakan sebuah ide iklan yang berbeda dengan kebanyakan iklan lain. Jika ide sebuah iklan sama saja dengan kebanyakan iklan lain, maka yang akan terjadi adalah iklan tersebut tidak akan dapat menembus perkumpulan iklan kompetitif lain dan sangat sulit untuk menarik perhatian khalayak konsumen. 
Media iklan paling efektif saat ini adalah melalui televisi dan media sosial seperti Instagram dan Facebook karena dapat menunjukan cara bekerja suatu produk pada saat digunakan. Iklan yang disiarkan di televisi dan media sosial dapat menggunakan kekuatan personalitas manusia untuk mempromosikan produknya. Melalui cara berbicara seseorang dan bahasa tubuh (body language) yang ditunjukan diyakini dapat membujuk audiens untuk membeli produk yang diiklankan tersebut. Pemasang iklan terkadang ingin menekankan pada aspek hiburan (sistem humor) dalam iklan yang ditayangkan dan tidak ingin menunjukan aspek komersial secara terang-terangan. Maka dari itu, pesan iklan yang ditampilkan tidak terlalu menonjol dan seakan memberi hiburan untuk pemirsa.

Iklan Shopee versi "pak Jokowi bagi-bagi sepeda" merupakan salah satu dari banyaknya iklan shopee. Pada iklan ini terdapat cerita ketika pihak paspampres mengalami gangguan yaitu belum datangnya hadian sepeda yang akan diberikan kepada seorang pelajar SD. Iklan tersebut dibut sekitar tahun 2017 lalu. Shopee memanfaatkan moment tersebut karena pada saat itu bagi-bagi sepeda sedang hangat diperbincangkan oleh kaum netizen Indonesia. Sisi kreatif yang menonjol pada iklan tersebut adalah ketika pak Jokowi menyentuh gambar sepeda pada smartphone dan saat itu juga tiba-tiba satu sepeda gunung muncul entah dari mana datangnya. Hal tersebut menunjukkan bahwa hanya dengan smartphone saja kita dapat membeli segala sesuatu yang kita inginkan tanpa harus pergi ke toko.

Iklan yang dimuat dalam televisi dan beberapa media lainnya itu menampilkan beberapa adegan yang menunjukkan bahwa Indonesia mempunyai beberapa suku dan kalangan yang ada di Indonesia mulai dari Suku Jawa hingga Papua, dan juga iklan tersebut memperlihatkan masyarakat desa dan kota yang semuanya akan dapat menikmati layanan aplikasi mobile market place tersebut. Seperti ketika ada pemirsa yang menonton televisi dan berbicara memakai Bahasa Jawa dan Papua itu menunjukkan bahwa Indonesia tercipta dengan berbagai suku dan bahasa. Pada iklan itu juga diperlihatkan ada beberapa pemirsa yang menonton televisi dengan berbagai keadaan, mulai dari di gubuk persawahan yang 
menunjukkan pekerjaan petani, di pinggir pantai yang menunjukkan pekerjaan nelayan, dan ada yang menonton televisi di rumah dengan duduk di shofa yang relative bagus yang menunjukkan orang-orang yang berkecukupan.

\section{b. Iklan Shopee Mengagetkan Pemirsa}

Roland Barthes pernah mengatakan di dalam penelitiannya tentang analisis buku yang berjudul Sarrasine yaitu tentang kode Hermeneutik atau biasa disebut dengan kode teka-teki yang merupakan suatu harapan dari pemirsa agar mendapatkan "kebenaran" kepada berbagai pertanyan-pertanyaan yang muncul dalam sebuah teks dan juga adegan. Di dalamnya terdapat suatu korelasi atau kesinambungan antara munculnya suatu peristiwa yang menimbulkan teka-teki dan penyelesaiannya di dalam cerita tentunya. Pada sub bab ini kami akan menganalisa tentang situasi dan kondisi juga body language yang digunakan pada iklan tersebut.

Suasana yang di tonjolkan pada scene pertama ketika seorang pelajar berdiri di sebelah podium pak jokowi adalah suasana damai yaitu ketika seorang presiden yang merupakan orang nomor satu di Indonesia dengan ramahnya berdiri dan memberi pertanyaan ringan kepada seorang pelajar yang masih dalam jenjang Sekolah Dasar. Hal tersebut sekaligus menunjukkan tentang kedamaian di negeri Indonesia. Pendekatan-pendekatan visual melalui pemberian hadiah tersebut di gunakan untuk meredam beberapa gejolak politis yang ada saat itu. Beberapa scene pada iklan ini menunjukkan tentang kekagetan masyarakat akan ketidak siapan pihak istana dengan belum tersedianya sepeda yaitu ditunjukkan dengan mimik muka seperti syok dan melotot ke arah televisi (bagi pemirsa). Pada scene tersebut kreator juga menampilkan suasana yang menunjukkan ke khas an negara tersebut yaitu dengan beberapa setting, mulai dari orang kaya yang menonton televisi di rumah dan duduk di sofa yang cukup bagus sampai orang-orang yang menonton televisi bersama-sama di warung. Hal tersebut memang sangat kental sekali ciri yang di tunjukkan mengenai kondisi masyarakat Indonesia. 


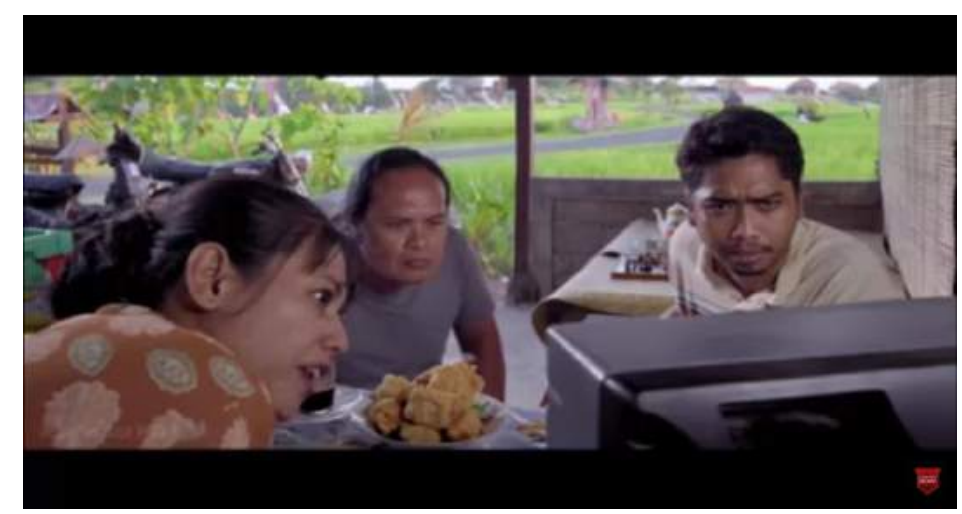

Sumber : Bagian Iklan Sophee

Bahasa tubuh selanjutnya yaitu pada scene inti, ketika sepeda yang tibatiba datang di samping pelajar. Ada beberapa hal yang perlu dijelaskan, yaitu , pertama adalah logo shopee yang ada di kiri atas layar memberitahu pemirsa bahwa iklan tersebut mempromosikan shopee atau bisa dikatakan sebagai identitas, kedua adalah seorang talent yang memeragakan pak Jokowi sedang memegang sebuah smartphone menunjukkan bahwa aplikasi shopee berada pada alat tersebut, ketiga adalah sepeda yang berada disebelah pelajar yang sedang memandang sepeda tersebut dengan keadaan kaget menunjukkan bahwa tanpa jauh-jauh pergi ke toko, hadiah datang dengan begitu cepat, terakhir adalah ekspresi senang setelah lega pada traut wajah pak Jokowi menunjukkan semua masalah dapat dipecahkan menggunakan aplikasi Shopee. Scene selanjutnya ketika semua orang ikut menggunakan aplikasi shopee yaitu scene dimana seluruh barang-barang yang ingin dibeli datang secara tiba-tiba di depan mata. Hal tersebut ada point utama yang ingin disampaikan oleh kreator pada iklan ini.

\section{c. Iklan Shopee Sebagai Iklan Parody}

Pertanyaan seorang pak Jokowi yang dimunculkan pada awal iklan "sebutkan Ibukota Sumatera Utara" menunjukkan bahwa ketika iklan ini dimuat saat itu memang "pak Jokowi bagi-bagi sepeda" masih sangat hangat diperbincangkan. Maka kreator iklan terinspirasi untuk memanfaatkan moment viral tersebut. Pada saat itu banyak sekali kejadian-kejadian di dunia nyata tentang guyonan-guyonan mengenai pertanyaan yang sederhana dan sepeda gratis pak Jokowi yang membuat beberapa artis pun ikut baper dalam kejadian tersebut. 
Yaitu ketika raisa yang ikut meminta sepeda saat pak Jokowi memintanya untuk menyanyikan sebuah lagu dalam suatu acara di istana negara.

Sebagai orang nomor satu di Indonesia, iklan tersebut menunjukkan wibawa seorang Presiden dengan menyerahkan semua urusannya kepada bawahannya yang merupakan Paspampres. Dari kebingungan mereka, terlihat bahwa ada kesalahan teknis ataupun yang lainnya sehingga hadiah belum bisa diberikan kepada pelajar tersebut. Dan para tamu pun ikut bingung karena memang hal tersebut seperti tidak seharusnya terjadi. Terlihat salah satu tamu menginformasikan kepada tamu yang lain bahwa sepeda yang akan dibagikan tidak ada di lokasi istana negara. Kejadian tersebut seakan membuat suasana di istana menjadi genting dan keadaan pada acara tersebut menjadi semakin runyam. Sehingga para wartawan pun memberitakan langsung untuk para pemirsa dirumah.

Iklan shopee juga menampilkan beberapa percakapan yang mengarah kepada suatu daerah atau suku tertentu. Kalimat "sepedahe ora onok" dan "sepeda ta ada" tersebut memang sekilas terdengar seperti guyonan semata, akan tetapi secara tidak langsung pada saat itu juga kreator iklan menunjukkan kekayaan bahasa yang di miliki oleh Indonesia. Dan begitu juga dengan istimewaan beberapa macam penduduk yang berbeda suku. Selain itu, pada iklan tersebut menunjukkan perokomian masyarakat yang berbeda-beda. Karena pada scene itu setting yang di gunakan adalah warung makan biasa dan juga kapal dipantai yang mengarah kepada tingkat perekonomian menengah kebawah.

\section{d. Drama Dalam Iklan Shopee}

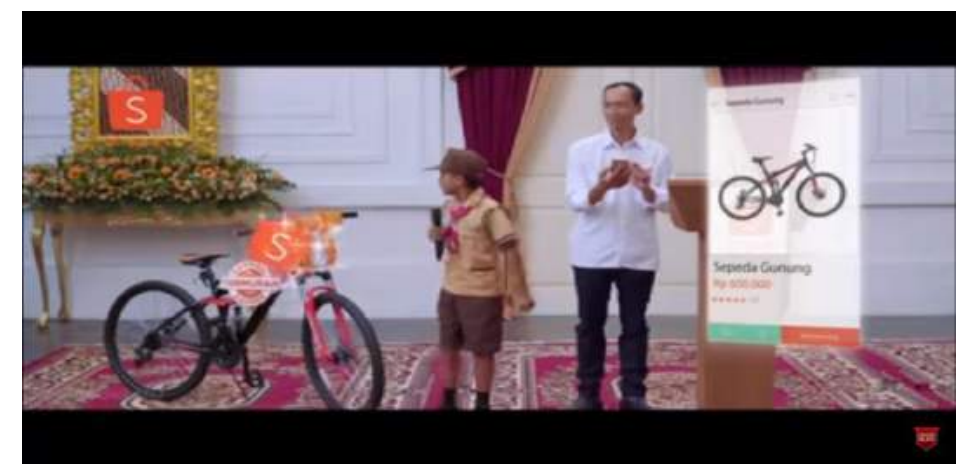

Sumber : Bagian Iklan Sophee 
Kreator memunculkan emosi pada iklan ini, ketika semua orang bingung dengan keadaan, ada suatu pemecahan permasalahan tersebut yaitu dengan cara memesan sepeda menggunakan aplikasi shopee itu sendiri. Kreatifitas dimunculkan para scene ini, kemunculan sepeda yang sangat tiba-tiba sebenarnya merupakan sebuah penjelasan kepada masyarakat bahwa ketika memesan barang melalui aplikasi shopee maka kita akan dimudahkan yaitu tidak perlu pergi ke toko dan hanya melalui gadget saja dan pengantaran barangnya pun sangat cepat. Pada waktu yang bersamaan baju pak Jokowi berganti dengan jaket bomber. Scene ini merupakan bagian dari scene sebelumnya ketika sepeda tiba-tiba muncul dan mempunyai makna yang sama dengan yang sebelumnya.

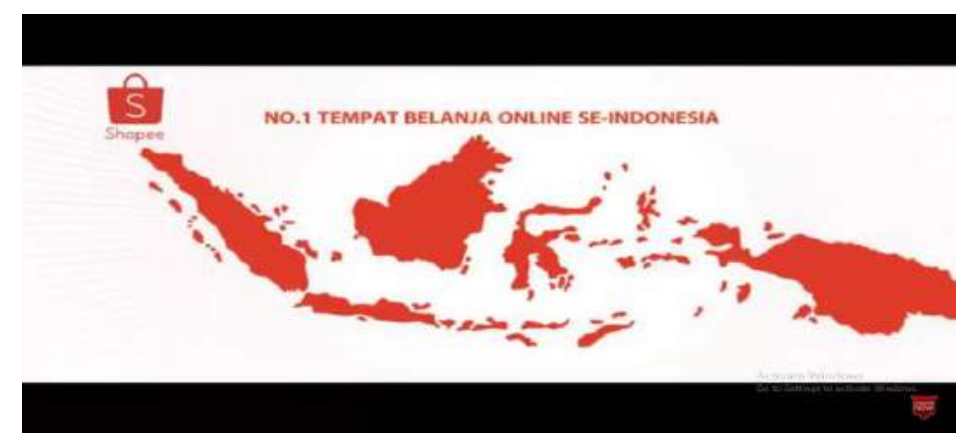

Sumber : Bagian Iklan Sophee

Beberapa kalimat yang dibacakan oleh narrator " hanya di shopee ada garansi harga termurah terbesar, termurah, gratis ongkir, garansi harga termurah se Indonesia" yaitu sebagai penjelas beberapa keterangan mengenai keunggulan aplikasi shopee dari pada aplikasi mobile market place lainnya yaitu pada kata "se-Indonesia" yang merujuk pada aplikasi saingan yang serupa. Selain itu, Gambar peta yang di tampilkan di akhir iklan menunjukkan bahwa progress yang telah di capai oleh shopee cukup signifikan. Dalam scene ini kreator mengirimkan pesan kepada pemirsa bahwa shopee sudah berada dan dapat mengirim barang keseluruh daerah yang ada di Indonesia.

\section{KESIMPULAN}

Iklan perusahaan Aplikasi e-commerce Shopee versi "pak Jokowi bagibagi sepeda" mempunyai kekreatifitasan yang cukup bagus, layak dan tentunya sangat menarik. Kreator memparodykan sesuatu yang viral saat itu yaitu sebagai pemanfaatan moment untuk menarik pelanggan. Hal tersebut termasuk salah satu 
ide yang jitu dari suatu biro iklan untuk menarik perhatian khalayak. Kendati kreatifitas yang tanpa henti, pesan dari iklan shopee selalu mudah untuk dipahami walaupun dengan metode unrational (tidak rasional) yang dimaksud disini adalah sesuatu yang tidak biasa (anti mainstream). Pemilihan alur ceritanya pun sangat menarik dan bahasa tubuh pada iklan ini sangat mudah di pahami sekelas tayangan iklan yang notabene mempunyai waktu yang cukup singkat.

\section{SARAN}

Iklan shopee mempunyai kelebihan yang sangat banyak, akan tetapi ada beberapa hal yang perlu di perhatikan dalam membuat iklan parody seperti iklan ini, yaitu iklan shopee terlalu banyak menapilkan "pemirsa" sehingga membuat durasi terlalu lama dan sedikit membosankan, seharusnya hanya di ambil beberapa saja tokoh perwakilan dari "pemirsa" itu sendiri agar dapat mempersingkat durasi iklan sehingga tidak terlalu membosankan dan pemirsa dirumah mau menonton sampai akhir iklan.

\section{REFERENSI}

Huda, A. M. (2009). Implementasi STOP SIT Pada Marketing Public Relations PT. Radio Unisi Prima Yogyakarta. Univerisitas Islam Negeriu Sunan Kalijaga Yogyakarta.

Huda, A. M., \& Martanti, D. E. (2018). Pengantar Manajemen Strategik 1. (J. Press, Ed.) (1st ed.). Bali:

http://books.jayapanguspress.org/index.php/publisher/article/view/18/18. Retrieved from http://books.jayapanguspress.org/index.php/publisher/article/view/18/18

Kover, Arthur J, Stephen M Goldberg, William L James. 1995. Creativity vs Effectiveness ? An Integrating Classification for Advertising. Journal of Marketing Research, Nopember December.

Shimp,A Terence. 2000. Promosi dan Periklanan. Aspek Tambahan Komunikasi Pemasaran Terpadu, Erlangga ,Jakarta.

Sobur, Alex. 2009. Semiotika Komunikasi. Bandung: PT Remaja Rosdakarya.

Till, D Brian, Daniel.W Baack. 2005. Recall and Persuasion, Does Creative Aadvertising Matter?. Journal of Advertising, Vol.34 No.3. Fall 2005 